\title{
Impatiens serusiauxii (Balsaminaceae), a new species from Marojejy National Park, Madagascar
}

\author{
Eberhard Fischer $^{1 *}$, Elisette M. Rahelivololona ${ }^{2,3}$ \& Dorothee Killmann ${ }^{1}$
}

\section{Article info}

Received: 16 Oct. 2019

Revision received: 9 Jan. 2020

Accepted: 8 Feb. 2020

Published: 2 Jun. 2020

Associate Editor

Nicolas Magain

\begin{abstract}
The new species Impatiens serusiauxii is described from Marojejy National Park in NE Madagascar. Impatiens serusiauxii differs from the morphologically similar I. manaharensis in the distinctly coriaceous linear-lanceolate leaves, the larger white flowers with dark red and yellow spots, the shape of the dorsal petal and the lateral united petals, and the shape of the lateral sepals and the lower sepal with spur oriented upwards. Impatiens serusiauxii is restricted to sclerophyllous montane cloud forest above $1100 \mathrm{~m}$.
\end{abstract}

Key words: Endemism, taxonomy, Impatiens manaharensis

\section{Introduction}

The genus Impatiens (Linnaeus 1753) (Balsaminaceae) is a monophyletic and diverse genus with more than 1000 species (e.g., Yuan et al. 2004; Janssens et al. 2009) and is represented by at least 260 endemic species in Madagascar (e.g., Fischer \& Rahelivololona 2002, 2004, 2007a, b, 2015a, b, c, 2016; Fischer et al. 2003, 2017). This island is one of the centers of species diversity for the genus, which is also the largest flowering plant genus on the island (Perrier de la Bâthie 1934, 1948; Humbert 1955, 1956; Fischer \& Rahelivololona 2002, 2004a, b, 2007a, b, 2015a, b, c, 2016; Fischer et al. 2003, 2017; Abrahamczyk \& Fischer 2015). Most of the Impatiens species are narrow endemics and thus have a very high potential risk of extinction. Fischer \& Rahelivololona (e.g., 2002, 2004a, b) initiated taxonomic studies of the Malagasy and Comorian members of Impatiens in an attempt to produce an updated flora of the family Balsaminaceae for Madagascar and the Comoros. Since then, 75 new species have been described and at least another 75 new species will be published in the near future (E. Rahelivololona \& E. Fischer, unpubl. data). The majority of the Malagasy Impatiens occur in the montane regions of northern and eastern Madagascar (e.g., Tsaratanana National Park with 36 species, Marojejy National Park with 48 species, Masoala National Park with 59 species).

\footnotetext{
${ }^{1}$ Institute for Integrated Natural Sciences - Biology, University of Koblenz-Landau, Universitätsstraße 1, 56070 Koblenz, Germany

2 Parc Botanique et Zoologique de Tsimbazaza, BP 4096, Antananarivo 101, Madagascar

${ }^{3}$ Université de Mahajanga, Mahajanga I 401, Madagascar

* Corresponding author e-mail: efischer@uni-koblenz.de
}

Marojejy National Park is located in northeastern Madagascar within the SAVA Region (a region with Sambava as the capital and composed of the first letters of the towns Sambava, Antalaha, Vohimaro and Andapa). With its tallest peak rising to $2137 \mathrm{~m}$, the area is home to a diverse flora of upland species. The wide range of elevations and the rugged topography of Marojejy create diverse habitats (Humbert 1955), which transition quickly with changes in altitude. There are four types of forests within the park: lowland rainforest below $800 \mathrm{~m}$; moist montane rainforest between 800 and 1100(-1400) m; sclerophyllous montane cloud forest between (1100-)1400 and $1800 \mathrm{~m}$; and ericoid shrub above 1800 m (Fig. 1) (Humbert 1955; Rahelivololona et al. 2018). The higher summits are covered by subalpine grassland with small ericaceous shrubs, and they are home to numerous local endemic species of Impatiens and of other large genera such as Streptocarpus (Gesneriaceae) and Helichrysum (Asteraceae). The park has been recognized as a center of plant endemism. For example, 32 palm species found in the Marojejy area are endemic to Madagascar, seven of which are restricted to the park (Dransfield \& Beentje 1995).

\section{Material and methods}

We investigated living plants in the field in Madagascar as well as dried specimens from BR, G, K, MO, NEU, $\mathrm{P}$ and TAN (herbarium acronyms after Thiers 2019). The standard terminology and measurements for Impatiens were described in detail by Fischer \& Rahelivololona (2002). 


\section{Results}

Taxonomy

Impatiens serusiauxii Eb. Fisch., Raheliv. \& Killmann, sp. nov.

(Figs 1-2)

Diagnosis: Impatiens serusiauxii differs from I. manaharensis in the distinctly coriaceous linear-lanceolate leaves (vs. ovate \pm herbaceous and soft leaves with a slightly crenate margin), the larger white flowers with dark red and yellow spots (vs. smaller pinkish flowers with dark pinkish to purple spots), the shape of the dorsal petal and the lateral united petals, and the shape of the lateral sepals and the lower sepal with spur oriented upwards (vs. spur curved downwards). Impatiens serusiauxii is restricted to sclerophyllous montane cloud forest above $1100 \mathrm{~m}$, while I. manaharensis is found in lowland rainforest below $800 \mathrm{~m}$.
Type: Madagascar, Antsiranana, Réserve Naturelle de Marojejy, along trail to summit of Marojejy Est, NW of Mandena, wet, evergreen forest between second and third camps, $14^{\circ} 26^{\prime} \mathrm{S}$ 49² 15-16'E, 1100-1200 m, 13 Feb. 1989, J. Miller \& P. P. Lowry 4034 (TAN - holotype!, MO!, P!, BR! - isotypes).

Description. Perennial herb, erect, glabrous. Stems succulent, green, up to 29-50 cm tall. Leaves alternate, fresh to dark green and shining above, pale green tinged purplish below, petiole $2-3 \mathrm{~mm}$ long, with $0-1$ pair of extrafloral nectaries, lamina linear-lanceolate, widest at middle, base attenuate, apex acuminate, $2.3-5.5 \times 0.4-0.9 \mathrm{~cm}$, with 4-5 pairs of secondary veins, margin dentate, with 6-7 pairs of teeth with gland-tipped appendages. Inflorescence axillary, with $1-2$ flowers. Peduncle $0.5 \mathrm{~mm}$ long.
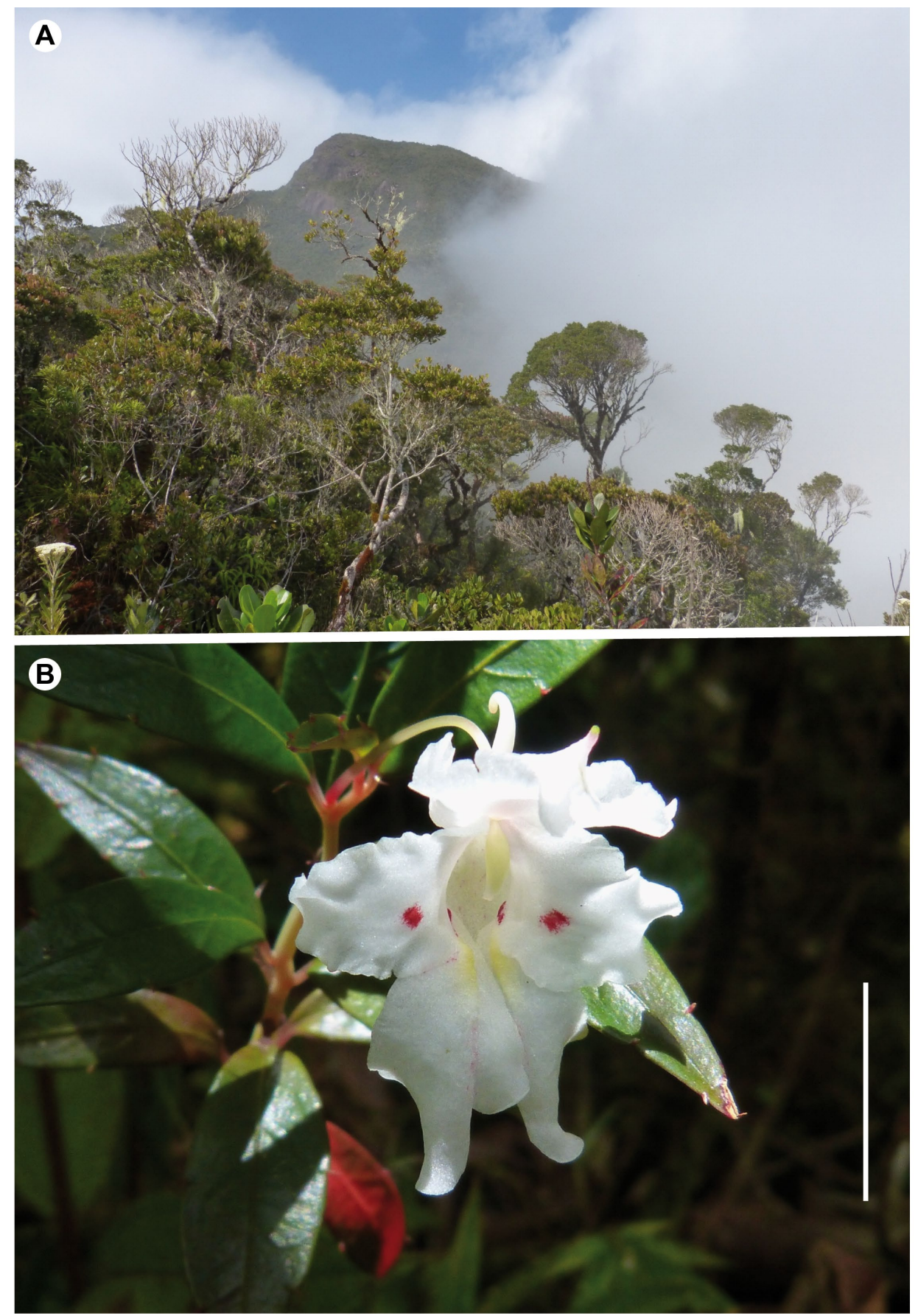

Figure 1. Impatiens serusiauxii. A - habitat above Camp III at $1250 \mathrm{~m}$; B - flower. Scale bar: B = $1 \mathrm{~cm}$. Photos by E. Fischer, 20.10.2014. 

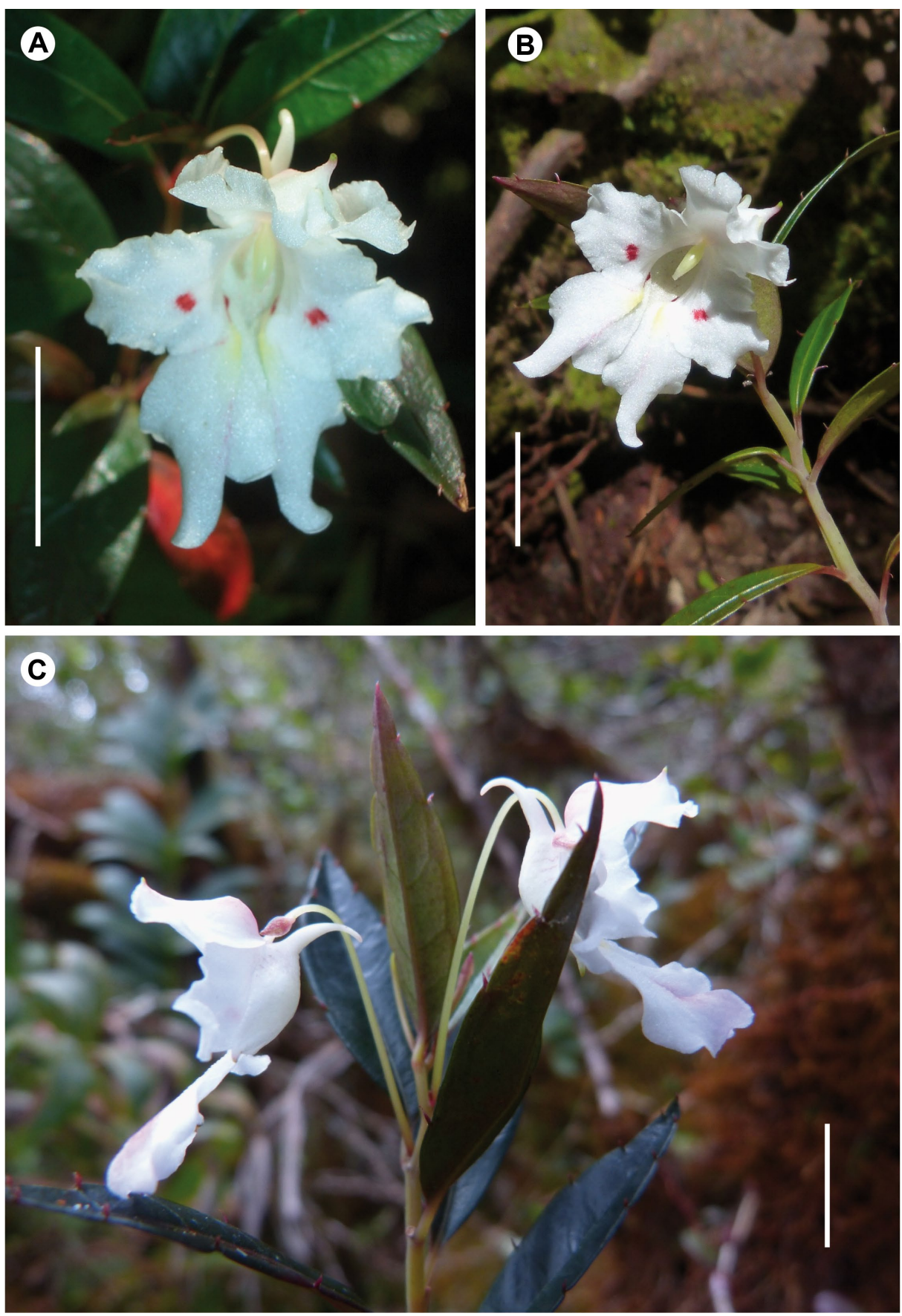

Figure 2. Impatiens serusiauxii. A - flower; B-C - detail of habit with inflorescence. Scale bar: A-C = $1 \mathrm{~cm}$. Photos by E. Fischer, 20.10.2014.

Bracts linear-lanceolate, $1-2 \times 0.5-1 \mathrm{~mm}$. Pedicels (2.6-) $3.5-4 \mathrm{~cm}$ long, distinctly curved at apex. Flowers white with two deep red and two yellow dots on lateral united petals, dorsal petal with greenish crest and apicule, lateral sepals white. Lateral sepals lanceolate, acuminate, 3-4 $\times 1-1.8 \mathrm{~mm}$. Lower sepal navicular, $13-15 \times 6-10 \mathrm{~mm}$, with apicule at base $1.5-1.8 \mathrm{~mm}$ long. Spur bent upwards and slightly curved, 5-6 $\mathrm{mm}$ long and $2 \mathrm{~mm}$ wide. Dorsal petal \pm cucullate, emarginate at apex and irregularly lobed at margin, 10-12 $\times 5-7 \mathrm{~mm}$, dorsal crest distinct, $1.5 \mathrm{~mm}$, apicule at apex 1-1.5 mm long. Lateral united petals $17-20 \mathrm{~mm}$ long, upper petal slightly emarginate at apex, 7-11 × $12 \mathrm{~mm}$, irregularly lobed at margin, lower petal deeply bilobed at apex, $8-12 \times 5-8 \mathrm{~mm}$, inner lobe shorter and rounded, outer lobe longer and falcate,
4-5 $\times 2 \mathrm{~mm}$. Anthers $2-4 \mathrm{~mm}$ long. Ovary $3-4 \mathrm{~mm}$ long. Fruit not known.

Ecology and distribution. Upper montane sclerophyllous cloud forest to ericaceous shrub, (1100) 1200-1500 m, Madagascar, known only from Mt. Marojejy.

Etymology. Dedicated to Prof. Dr. Emmanuel Sérusiaux, who accompanied the first author on a field trip to Marojejy where this new species was discovered.

Vernacular name. Benga, Andriana fotsy.

Specimens examined. MADAGASCAR. Réserve Naturelle Intégrale 12 Marojejy, au Nord d'Andapa, aux environs du sommet de l'Est, $14^{\circ} 29^{\prime} \mathrm{S} 49^{\circ} 38^{\prime} \mathrm{E}, 1300-1500 \mathrm{~m}, 21-22$ Jan. 1994, F. Rasoavimbahoaka, B. Lewis, J. Mc Donagh, S. Malcomber 


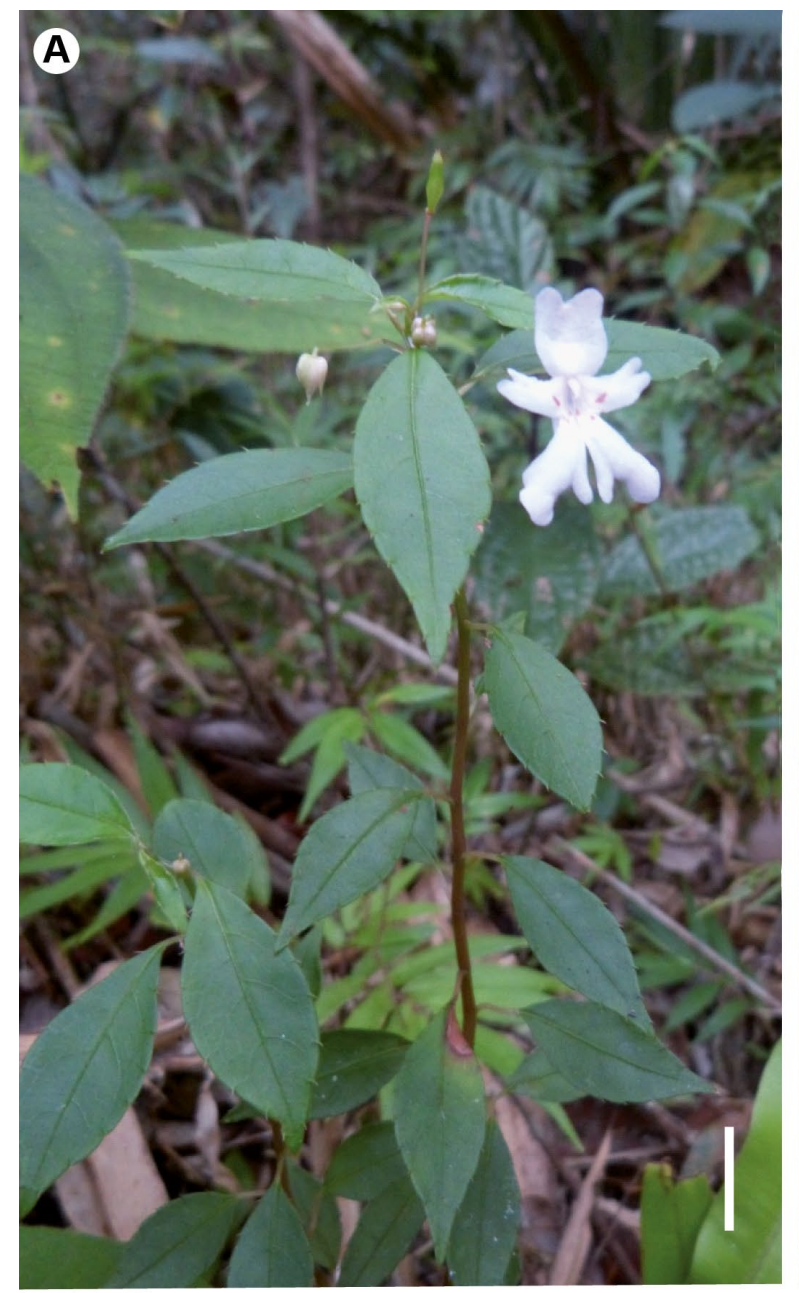

B
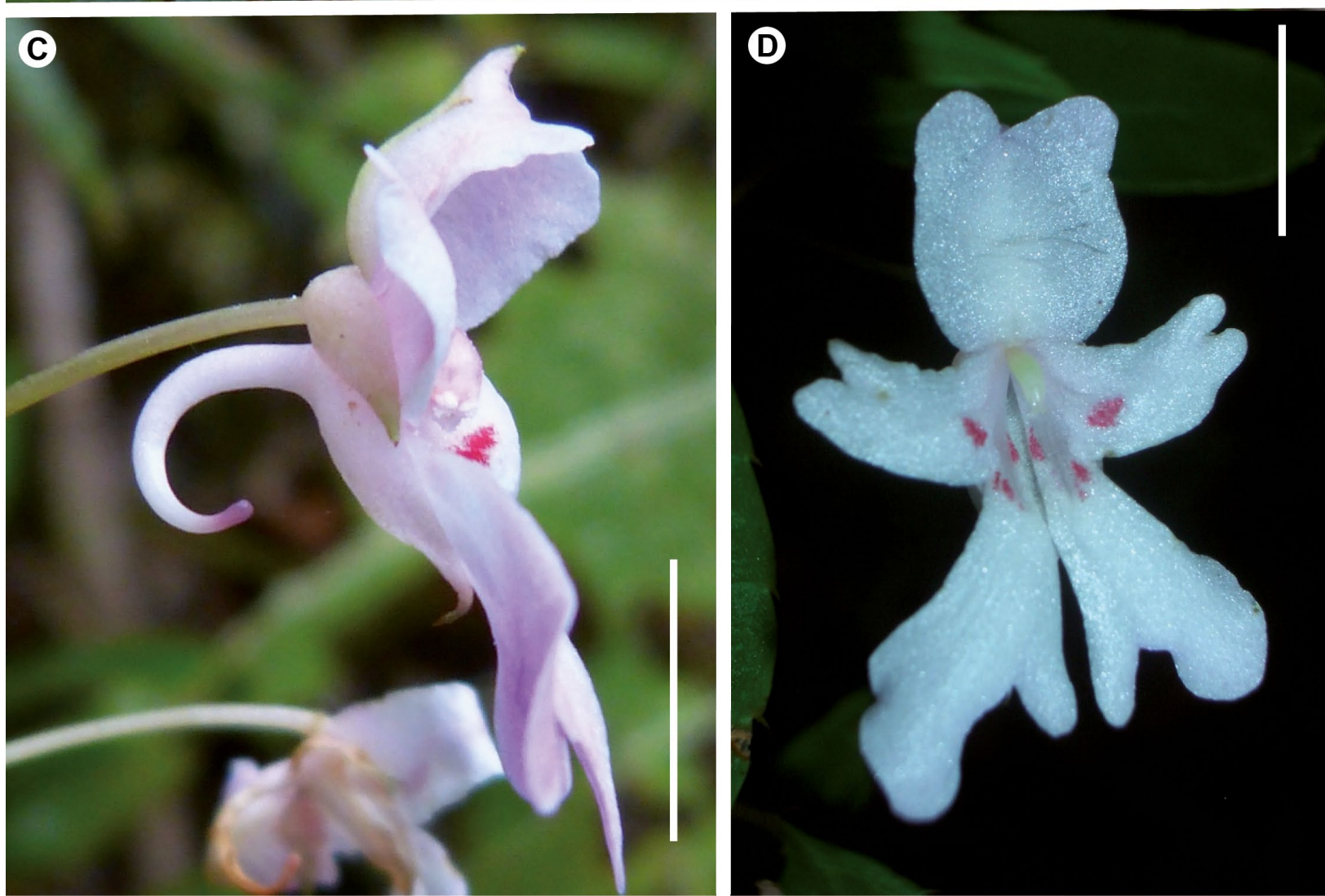

Figure 3. Impatiens manaharensis. A-B - habit; $\mathrm{C}-$ flower, lateral view; $\mathrm{D}-$ flower, frontal view. Scale bar: $\mathrm{A}-\mathrm{D}=1 \mathrm{~cm}$. Photos by $\mathrm{E}$. Fischer, 18.10.2014. 
\& C. Voninera 31 (TAN, MO, P); Réserve Nationale 12 Marojejy - sentier qui mène au 3ième camp, au dessus du village Manantenina, 1150-1300 m, 26 Mar 1990, A. Randrianasolo 89 (TAN, MO); Antsirana, Marojejy RNI, Sambava, environ à $13,5 \mathrm{~km}$ à vol d'oiseau au nord est de Maroambihy et $9,5 \mathrm{~km}$ à vol d'oiseau au nord est du fokotany de Mandena et le sommet de Marojejy, $1200 \mathrm{~m}, 14^{\circ} 26^{\prime} 10^{\prime \prime} \mathrm{S}, 4^{\circ} 44^{\prime} 25^{\prime \prime} \mathrm{E}$, s.dat., F. Rasoavimbahoaka 576 (TAN, MO).

Conservation status. EOO: not applicable, AOO: 9 km², number of locations: not applicable (IUCN 2016). With only one collecting site where Impatiens serusiauxii has been observed, it is not possible to calculate the extent of occurrence (EOO). The area of occupancy (AOO) falls within the limits for the Critically Endangered category under sub-criterion B2. However, as the single collecting site occurs inside a well-protected area (Marojejy National Park), it does not face degradation or loss of habitat and is not in decline. Thus, the necessary conditions required under sub-criterion B2 are not met, and the species cannot be placed in any threat category. Therefore it is listed as Least Concern (LC), and because its entire occurrence is within a protected area, the label Conservation Dependent (CD) has been added.

\section{Discussion}

Specimens of Impatiens serusiauxii were usually identified as Impatiens manaharensis Baillon (1886). However, Impatiens manaharensis differs in the ovate \pm herbaceous and soft leaves with a slightly crenate margin (vs. distinctly coriaceous linear-lanceolate leaves), the pinkish flowers with dark pinkish to purple spots (vs. white flowers with dark red and yellow spots), the shape of the dorsal petal and the lateral united petals, and the shape of the lateral sepals and the lower sepal with a spur that is curved downwards (vs. spur oriented upwards) (Fig. 3).

Impatiens manaharensis also occurs at Mt. Marojejy but is found only in lowland rainforest below $800 \mathrm{~m}$. The plants agree very well with the type (Madagascar, Manahar, Humblot 218, P - holotype!, $\mathrm{K}$ - isotype!). In a paper dealing with the phylogeny of Impatiens in Madagascar (Rahelivololona et al. 2018), Impatiens manaharensis is resolved in a sister clade to $I$. serusiauxii (there called I. aff. manaharensis) and I. max-huberi, also endemic to Marojejy and the adjacent Anjanaharibe-Sud area (Fischer \& Rahelivololona 2016).

\section{Acknowledgements}

We thank the Directors of the following herbaria for loan of specimens (acronyms according to Thiers 2019): BR, G, K, MO, NEU, P, TAN. We are indebted to the Missouri Botanical Garden, Parc Botanique Zoologique Tsimbazaza and Madagascar National Parks for research and collection permits. The Akademie der Wissenschaften und Literatur Mainz kindly sponsored the field trip of the first author. Special thanks to our colleagues Emmanuël Sérusiaux (Liège), Damien Ertz (Meise), Bernard Goffinet (Connecticut) and Roger Lala Andriamiarisoa (Antananarivo), who accompanied us in the field in 2014. Without the skills of Roger Lala Andriamiarisoa, the field work would have been impossible.

\section{References}

Abrahamczyk, S. \& Fischer, E. 2015. Impatiens elianae (Balsaminaceae), a new species from central Madagascar, with notes on the taxonomic relationship of I. lyallii and I. trichoceras. Phytotaxa 226: 83-91.

Baillon, H. E. 1886. Liste des Plantes de Madagascar. Bulletin Mensuel de la Societé Linnéene de Paris 1: 594-600.

Dransfield, J. \& Beentje, H. 1995. The Palms of Madagascar. Royal Botanic Gardens, Kew and The International Palm Society.

Fischer, E. \& Rahelivololona M. E. 2002. New taxa of Impatiens (Balsaminaceae) from Madagascar I. Adansonia 24: 271-294.

Fischer, E. \& Rahelivololona, M. E. 2004. New taxa of Impatiens (Balsaminaceae) from Madagascar III. Adansonia 26: 37-52.

Fischer, E. \& Rahelivololona, M. E. 2007a. New taxa of Impatiens (Balsaminaceae) from Madagascar IV. Adansonia 29: 269-315.

Fischer, E. \& Rahelivololona, M. E. 2007b. New taxa of Impatiens (Balsaminaceae) from Madagascar V. New species of Impatiens from Masoala Peninsula Adansonia 29: 317-332.

Fischer, E. \& Rahelivololona, M. E. 2015a. New taxa of Impatiens (Balsaminaceae) from Madagascar IX. Impatiens lutzii, a new species from Montagne d'Ambre National Park. Phytotaxa 239: 183-189.

Fischer, E. \& Rahelivololona, M. E. 2015b. New taxa of Impatiens (Balsaminaceae) from Madagascar VII. Two new species of Impatiens from Mt. Marojejy, Madagascar. Phytotaxa 239: 213-222.

Fischer, E. \& Rahelivololona, M. E. 2015c. New taxa of Impatiens (Balsaminaceae) from Madagascar VI. Impatiens otto-eleonorae, a new species from Masoala Peninsula, and notes on the taxonomic relationships of Impatiens firmula and I. hildebrandtii. Phytotaxa 217: 155-163.

Fischer, E. \& Rahelivololona, M. E. 2016. New taxa of Impatiens (Balsaminaceae) from Madagascar VIII. Impatiens maxhuberi, a new species from Marojejy and Anjanaharibe-Sud. Phytotaxa 244: 191-195.

Fischer, E., Rahelivololona, M. E. \& Abrahamczyk, S. 2017. Impatiens galactica (Balsaminaceae), a new spurless species of section Trimorphopetalum from Madagascar. Phytotaxa 298: 269-276.

Fischer, E., Wohlhauser, S. \& Rahelivololona, M. E. 2003. New taxa of Impatiens (Balsaminaceae) from Madagascar II. A collection from Masoala Peninsula. Adansonia 25: 17-31.

IUCN (2016) The IUCN Red List of threatened species - 2001 Categories and Criteria, Version 3.1. Available from: www.iucnredlist.org./ static/categories_criteria_3_1 [accessed 6 January 2020]

Janssens, S. B., Knox, E. B., Huysmans, S., Smets, E. F. \& Merckx, V. S. 2009. Rapid radiation of Impatiens (Balsaminaceae) during Pliocene and Pleistocene: result of a global climate change. Molecular Phylogenetics and Evolution 52: 806-824.

Linnaeus, C. 1753. Species plantarum. L. Salvius, Stockholm.

Humbert, H. J. 1955. Une merveille de la nature à Madagascar. Première exploration botanique du massif de Marojejy et de ses satelittes. Mémoires de l'Institut Scientifique de Madagascar Série B, 6: 1-210.

Humbert, H. 1956. Contributions à l'étude de la Flore de Madagascar et des Comores. Notulae Systematicae (Paris) 15: 113-118.

Perrier de la Bâthie, H. 1934. Les Impatiens de Madagascar. Archives de Botanique 7(1933), Mémoire 1: 1-124.

Perrier de la Bâthie, H. 1948. Révision des Impatiens de Madagascar et des Comores. Mémoires de l'Académie des Sciences (Paris), Sér. 2, 67: 1-16.

Rahelivololona, E. M., Fischer, E., Janssens, S. B. \& Razafimandimbison, S. G. 2018. Phylogeny, infrageneric classification and species delimitation in the Malagasy Impatiens (Balsaminaceae). Phytokeys 110: 51-67.

Thiers, B. 2019. Index Herbariorum. http://sweetgum.nybg.org/science/ih/

Yuan, Y.-M, Song, Y., Geuten, K., Rahelivololona, E., Wohlhauser, S., Fischer, E., Smets, E. \& Kuepfer, P. 2004. Phylogeny and biogeography of Balsaminaceae inferred from ITS sequences. Taxon 53: 391-403. 